Journal of Humanities, Social and Management Sciences (JHSMS)

eISSN: 2788-4791 (online)

https://doi.org/10.47264/idea.jhsms/2.2.12

Vol. 2, No. 2 (July-December 2021), 168-180

https://www.ideapublishers.org/index.php/jhsms

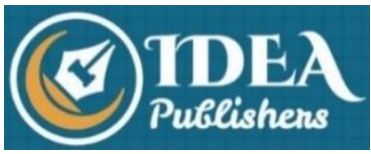

Research Article

\title{
Role of religion in American politics: An analysis of the influence of Evangelical Church in Israeli Palestinian conflict
}

\author{
Fida Muhammad*1 ${ }^{1}$ Muhammad Ayaz Khan ${ }^{1}$ | Saif Ul Islam² \\ 1. Department of Political Science, Hazara University, Mansehra, Pakistan. \\ 2. Department of Political Science, University of Buner, Sowari, Pakistan. \\ *Corresponding Author Email: shanglawale@yahoo.com
}

Received: April 30, 2021

Published: November 23, 2021

\begin{abstract}
The politics of the Holy land is of crucial importance to the followers of the three Abrahamic religions in terms of religious beliefs, which metamorphosed into military and political significance in the $20^{\text {th }}$ Century. The United States (U.S) support for Israel is especially visible during the republican presidencies. The U.S had five republican presidents from 1980 to 2020, and their evangelical beliefs shaped American foreign policy toward this region, a policy that may loosely be termed as affected by Christian Zionism, which was originally a 16th Century religious Puritan movement, who latter shaped into Christian political movement. U.S Christian Zionism reiterates favourable images of Jews and is pessimistic about peace in Holy land. Christian Zionists believe Lord has bestowed the land of Palestine to Jews and have held up this claim since the turn of the 20th Century. This paper first describes the fundamental nature of Christian Zionism, their view of the modern Israel and resultant political and military policies. This also focuses Christian Zionists support of republican presidents and specially President Trump relationship with Christian Zionism. The shifting of U.S embassy to Jerusalem, the formal approval to Jerusalem as the capital of Israel by President Trump are studied.
\end{abstract}

Keywords: United States foreign policy, Middle East, Christian Zionism, Christian right, religion and peace, apocalypse, dispensationalism, evangelicals.

How to Cite: Muhammad, F., Khan, M. A., \& Islam, S. U. (2021). Role of religion in American politics: An analysis of the influence of Evangelical Church in Israeli Palestinian conflict. Journal of Humanities, Social and Management Sciences (JHSMS), 2(2), 77-89. https://doi.org/10.47264/idea.jhsms/2.2.7

Publisher's Note: IDEA PUBLISHERS (IDEA Publications Group) stands neutral regarding jurisdictional claims in the published maps and institutional affiliations.

Copyright: @ 2021 The Author(s), published by IDEA PUBLISHERS (IDEA Publications Group).

Licensing: This is an Open Access article published under the Creative Commons AttributionNonCommercial 4.0 International License (http://creativecommons.org/licenses/by-nc/4.0/) 


\section{Introduction}

A number of internal and external factors are seen as the reason for the exceptionally close ties between Israel and United States (U.S). Strategic and economic interests are the international elements while the American Jewish community and Judeo-Christian heritage are domestic factors for this alliance. Executive is responsible for much of the foreign policy formation in the U.S. The U.S Congress is always an apostle of Israel. This pro-Israel posture of the Congress and most presidents after the Second World War largely represented the general will of the American society. Apart from the Jewish lobby, which is powerful at domestic level, another group, Christian Zionist plays an important role to influence U.S foreign policy regarding Israel. Most believers of this group hold an eschatological belief, dispensationalism. This belief states that Bible already told the imminent Second coming of Jesus and missionaries, like other dispensationalists, were fascinated and encouraged by the Jewish national revival (Ariel, 2000).

The Christian right arose from liberalizing tendencies in American culture throughout the 1960s and 1970s brought Christian Zionism into mainstream politics with a pro-Israel motive. Moral majority was found in 1979 which gained evangelical Christian support for Republican Party and to ice that the Republicans hugged a Christian Right program. Historically, it was Reagan who had supported Christian Right agenda and won their support during his election. During the Trump administration Christian Zionists again rose to prominence. They are very vocal in support of Donald Trump and who have close ties with evangelicals and thus makes him implausible vessels of Christian Zionists aspirations.

\subsection{Jewish Zionism}

Theodor Herzl was the founder of Jewish Zionism, and it is completely different from Christian Zionism. Zionism is "the creation of a Jewish homeland and undertook political steps to bring about its realization", (Cohn-Sherbok, 2012).

\subsection{Christian Zionism}

The term is generally used for any "Christian who support Israel today or have endorsed Zionists projects in the past on the basis of very different understanding of God's word and well" (Goldman, 2018). Similarly, Specter (2009) explained Christian Zionism as, "any Christian who supports the Zionist aim of building the state of Israel, its army, government, and other institutions" (Spector, 2009).

\subsection{Restorationism}

Restoration is a belief that Jews will return to Holy land, and it is prophesized in the Bible (Sizer, 2005).

\subsection{Pro-Israel}

This term describes a positive and supportive attitude to the Jewish people. This is not a system of ideas and does not comprise a movement. 
Role of religion in American politics: An analysis of the influence of Evangelical Church ...

\subsection{Evangelicals}

The evangelical is a religious movement within Protestantism and follow some basic beliefs; commitment to the Bible, the importance of missions, spiritual life and that "religion has always focused on the Gospel, the good news that Christ's sacrifice on the cross has made salvation available to mankind" (Spector, 2009).

\subsection{Dispensationalism}

The dispensationalists believe on the literal interpretation of the Bible. Therefore, according to the dispensationalist eschatological narrative, the Jews would return to the Palestine land to build an independent political state, thereby preparing the way for the arrival of the Messiah (Ariel, 2000).

\section{Literature review}

A lot of literature has been written on Evangelicals and U.S unilateral endorsement for Israel. It has been discussed in various television programs and also in a number of Magazines and articles. Christian Zionists have also Facebook pages such as Evangelical Reinhard Bonnke and Ministries of John Hagee. However, we cannot find impartial study on the subject regarding the activities of Evangelical and policy makers in white house. Current academicals achievements have focused different causes for the Middle East conflict. Most Scholars believe that economic and strategic interests weigh more than the religious belief in the minds policy of makers.

Some authors perceive those religious dogmas can guide external relations of a country to some extent; still, it is not the basic impulse. As in Abrams (2002) opinion, religion was not the cause of U.S success and it is more comparable to French revolution. Similarly, Charles Krauthammer (2004) sees insignificant place for the Gospels of the Bible to influence the foreign policy. Abrams (2002) in his book "The influence of faith" mentioned it is fruitless to see for a domino effect and casual sequence ties between religion and foreign policy. Instead, he looks the position of religion in some other place, as moral rather than political. Stephen (2009) argues that evangelical's designs are complicated, and they have alliance with Israel against terrorism as well as biblically based firm belief that God truly promised the land to Jews. The author offers more than the standard explanations for the exceptionally close relationship between evangelicals and Israel. The deficiency in his work is he provides little about the domestic support for Israel in America.

Terry (2005), focused on how the lobbies and interest groups influence U.S foreign policy. Terry draws the Sinai accords and Camp David accords as case study to explain the role of lobbies. She also explains the major Arab boycott. But she did not focus on the influence Christian Zionist ideology in U.S politics and she heavily focused on political campaigns of presidential candidates. Faud Shaban discussed Christian Right in the U.S. politics, Zionism and its relationship to Orientalism. This has led to the formation of a Judeo-Christian tradition in the American culture. He also mentioned that President George Bush also believed such ideologies in White House, which drive his foreign policy. He often neglected and marginalized, in consolidating the faith, Christian thoughts, the rites, the rituals and the doctrine. 
The above brief literature review shows that American support for Israel is founded on international factors as well as domestic elements for instance the American Jewish community, Christian Zionism and Judeo-Christian heritage. However, the literature has a gap regarding the evangelicals' activities and their relations with Republican presidents and especially with President Trump.

\section{Theoretical and methodological approach}

The theory used in this paper is liberalism. Liberalism focuses on the actors within the states, such as the Christian Zionist lobby and the Jewish lobby. These actors within society advocate policies to increase U.S support for Israel. This results into a strong friendship between U.S and the state of Israel. In foreign policy formation domestic groups such as the Christian Zionists lobby advocating their own preferences regarding Israel. These domestic actors in Liberalism, the theory states that it is the lobbying forces or interest groups within the states and not the international system that determines a state's preferences. As pointed out by Van Shannon "US Congress came to be so pro-Israel may have a lot to do with the second domestic force in the Arab-Israeli conflict: interest groups" (Shannon, 2003).

This paper encompasses a qualitative analysis of the effects of evangelical's groups on decision makers in U.S regarding Israel-Palestine conflict. The article consists of an analysis which includes both currently published data as well as historical facts and figures that gives a framework to the issue. Keeping in view the Christian Zionists groups and Republican presidents, the online and print media is great asset in exploring the inter-relationship between the U.S, Israel and Evangelicals groups. Secondary data such as books, journal articles and newspapers were used to understand the domestic activities of evangelicals with key politicians. Books, journal articles and newspapers, speeches by the state's spokesmen, are helpful in understanding the latest controversial issues and future dynamics.

\section{Role of religion in American politics amidst Israeli Palestinian conflict}

\subsection{Theological origins of Christian Zionism}

To understand the importance of the state Israel and Jews to Christian Zionists in the U.S, it is important to know from where they extrapolate their beliefs. The foundations of Christians Zionism have come from dispensationalist thoughts. It is delineated by Weber (2004) as "an intricate system that tried to explain the stages of God's redemptive plan for the universe". The philosophy of dispensationalism has its shadow on a large congregation of Zionist in U.S. Dispensationalism has its "origins back to the early nineteenth century and the teachings of John Nelson Darby (1800-81) and the Plymouth Brethren” (Marsden, 2008).

Darby and the Plymouth Brethren Minister elucidate parts of the Book Isaiah and arrived at a judgment that Jews were separate nation from Christians. Darby used this Dispensationalist theology to explain the Bible through a series of prophecies and these interpretations thus laid the foundation of Christian Zionism. Darby separated Israel and Church in God salvation plan. The world history, claimed by Darby "can be divided into seven time periods, or dispensations, beginning with the Garden of Eden and ending with the second coming of Christ, his thousandyear reign with the Church (the millennium), followed by the judgment of the unbelievers" (Marsden, 2008). The word dispensation is used many times in the New Testament. Darby 
Role of religion in American politics: An analysis of the influence of Evangelical Church ...

explains the word dispensation mean that God will deal humanity in a series of different times or "dispositions". Of the seven dispensations millennium is the last one of these. Sizer (2005) explained Darby dispensationalism as (a) Paradisaical state; (b) Noah; (c) Abraham; (d) Mosses; (e) Spirit; (f) Grace (g) Millenium.

According to dispensationalists the story in the Bible is "the complete separation of Israel and Church into two plans of God" (Weber, 2004). So, in such thinking, God has pledged the Jerusalem in Old Testament to Semites. They see the current nation of Israel as the accomplishment of Biblical revelations. Christian Zionists also see the fate the spiritual families of Jesus are obligated to the doom of Israel in two evident but separate accord. Marsden (2008) describes this belief as "the first covenant is with physical descendants of Abraham, through Isaac not Ismail, namely the Jews. The second covenant is with the spiritual descendants of Abraham, the Church."

According to the Christian Zionists, the world is in the concluding sixth phase which is the grace age. These revelatory prophecies are in details in the books of Bible such as Ezekiel, Daniel and Revelation. These biblical prophecies according to Christian Zionists are a guideline to explicate approaching seventh age, arrival of Jesus and his millennial empire. Crucial to the paper, Christians Zionists addresses "without a restored Jewish state, there could be no Antichrist, no great Tribulation, no battle of Armageddon, and not second coming" (Weber, 2004).

Before the second coming of Jesus Christ, there must be a series of events on the earth. These include the ingathering of Jews to the Holy land, Jerusalem as their metropolis, and reconstruction of ancient templum of prophet Soloman on Dome of Rock. False Messiah will revolt, and a last combat called Harmagedon between the Messiah and Satan in which Satan shall be defeated by Christ. "This will take place, according to Christian Zionist, at Mount Megiddo in Israel. Just in time Jesus will return with all the church, those who were raptured and win a decisive victory before the establishing a reign with his church that will last thousand years" (Weber, 2004). So, the birthplace of Christian Zionism is Great Britain.

In Medieval times Christian attitudes about Jews were determined by "replacement theology," which was largely based on Old Testament. Their take on Jewish Diaspora, Jews were under God's curse because they did not accept Jesus as a Messiah. The Calvinists rejected this allegorical interpretation. The Protestants look at Jews in a more friendly way. Protestants portrayed Hebrew prophets and heroes as the figures of Christian's self-identification. This change occurred during the Seventeen Century when societal condition in Britain was worst. Further, there was a perception that the National Church of England being corrupt helped the puritans to promote their dispensationalist view. On the basis of Biblical Revelation, they formed puritan colony of Masochistic and anticipated it as God Kingdom. The puritan's preachers produced many "end times" literature in Great Britain. They favoured a theocratic form of government which would be characterized by the restoration of political power to the members of the church.

Sharif (1983) holds that non-Jewish Zionism was an integral element in Western religious, social and political history, forming a parallel to and not an annex to the history of Jewish Zionism. So, we can say that the origin of Christian Zionism lies outside Jewish history. The restorationist tradition was developed in Britain in $17^{\text {th }}$ Century; different Western nations hold 
essentials of this conception inherent in their own mores. John Locke and Isaac Newton were the early expositor of scriptural prophecies and the ingathering of Semitic tribes to Palestine. "Newton interpretation of prophecy foresaw the return of the Jews to Israel in the End Times. The actual fulfilment of this prophecy came with the events that occurred at the beginning of the past century. Finally, the prophetic fulfilment of Newton's interpretation that the Jews will return to the holy land was confirmed in 1948 with rebirth of Israel" (Prophet, 2009).

Napoleon was the first European states man who put forward for consideration a Jewish state and not Herzl or Balfour. Sizer explained this as "he becomes the first political leader to propose a sovereign Jewish State in Palestine" (Sizer, 2004). There was "Renewal of interest in prophecy which eventually led to a revival of Premillennialism within mainstream and sectarian Evangelicalism" (Sizer, 2005) during the first and the second decade of 1800 Century. Despite of all these developments there was no organized movement until John Nelsen Darby developed "dispensationalism."

In Britain the Earl of Shaftsbury was had a strong belief of restoration of Jews to the Holy land. Shafts Burry strived for a Jewish state and lobbied for it in the Britain. Shaftsbury wrote that Palestine is a country without people; and the Jews are a people without a country (Clark, 2007). William Hechler was another influential Christian Zionist. He was a British priest who became a member of the British clergy in 1885, served in Vienna and strived for Jewish cause, "the restoration of the Jews, that same vital step along the way to the thousand years of peace and Jesus's Second Coming, had galvanized William Hechler into action with Dr. Herzl" (Clark, 2007).

\subsection{Christian Zionism in America}

The Christian Zionism, while came into existence in the England, it began making its way transatlantic and into the minds of the Americans. Darby made missionary visits "in North America, making seven journeys in the next twenty years" (Sizer, 2004). Darby put much influence over the evangelical leaders. Darby brought about a number of religious leaders to his cult of dispensationalism and thus, to Christian Zionism. As Theodore Herzl is called of Jewish Zionism; we can say that Darby is the father of Christian Zionism. He impressed James Brooks, Moody, and W.E Blackstone during his visit of the America. His main sources were the Biblical books to in lace a final picture of the world's end times. William Black stone is another one among the earliest American evangelicals as he publicly supported a Jewish homeland in the Palestine.

Blackstone was an evangelical who at the age of eleven began attending evangelical protestant gatherings. He became very famous for his book Jesus is coming. Cyrus Scofield is thought out an inspiring component of dispensationalism. The Scofield bible gained a widespread popularity in America and his thoughts were much influenced by Darby philosophy. According to him there are three categories of folks, Semites, Church and Gentiles.

\subsection{US domestic politics and Christian Zionists involvement in the Holy land conflict}

Israel-Palestine conflict is a big issue for the Muslim world and especially for the Middle Eastern countries. American involvement in the region is obvious and it is very important to study the roles of its decision makers since there is involvement of orthodox in Republican 
Role of religion in American politics: An analysis of the influence of Evangelical Church ...

Party. The importance of Israel in the U.S diplomacy is obvious mostly in the course of election campaign in which no presidential contender takes the side of Palestinians. This led to the spread of prejudice and hatred against America in the Muslim World, and it equivocate the reason for this one-sided approach of Eretz Yisrael. Mearsheimer and Walt (2006) states that, "treating Israel as America's most important ally in the campaign against terrorism and against assorted Middle East dictatorships exaggerates Israel's ability to help on these issues, overlooks how the relationship contributes to these problems, and ignores the ways that Israel's policies make U.S efforts to address them more difficult". Majority of Christians support a two-state solution consisting of a sovereign state of Palestinian and Israel exist in peace and harmony. Christian Zionism, however, opposes these solutions and all such things considered as barriers to reconciliation in the Middle East.

The prospective impacts of Christian fundamentalists are much more significant compared to the Jewish lobby, because of their large numerical superiority. "Evangelicals outnumbered Jews; perhaps 60 million to six million, and the Christian Zionists among them were at the least compromising advocates of maximalist Israeli positions" (Thomas, 2007). Apart from this Clark pointed out:

"If the rest of the world can afford to ignore the American Religious Right's domestic stances on abortion, Creationism, stem-cell research and gay marriage, it urgently needs to understand Christian Zionism - the guiding principle of its foreign policy in the Middle East" (Clark, 2007).

The year 1948 was a momentous year for modern Christian Zionists. In the evangelical theology the ingathering of the Semitic tribes to the Holy land was a grand event. This prophecy is described by a Christian Zionist, Carol Bufardi in an online discussion as "The Bible is full of prophecies that have been fulfilled and the Jews becoming a nation in 1948, and you will soon see their $3^{\text {rd }}$ Temple erected toward the North of the Dome of the Rock" (Bufardi, 2014). Israel was formally announced $15^{\text {th }}$ May 1948 and President Truman rapidly acknowledged de facto recognition to it.

The first major sign of Eschatology for Christian Zionists was the creation of Israel. It was seen by Christian Zionists as fulfilment of God covenant with Ibrahim. The next serious sign of end time's theology was now the control of Jerusalem. The third Arab Israel War inspired Southern Baptists in support of Israel. In this war, Israel occupied the ancient land of Samaria, Judea and the city of Jerusalem. Billy Graham's expressed the sentiments of the evangelicals "for the first time in more than 2000 years. Jerusalem is now completely in the hands of the Jews which gives a student of the Bible a thrill and a renewed faith in the accuracy and validity" (Sizer, 2005). The Christian Zionists saw the June war as execution of the Biblical predictions. The American fundamentalists made tours to the Palestine land. It helped to grow the commodity of Israeli economy and provided a solid foundation for the ties between the American evangelicals and Israel.

The Southern Baptists quote verse 12; 3 from Bible "I will make you into a great nation and I will bless you; I will make your name great, and you will be a blessing. I will bless those who bless you, and whoever curses you I will curse; and all peoples on earth will be blessed through you" (Timothy \& Shaw, 2019). Based upon this belief the Christian Zionist asks publicly the western world to support Israel commercially and politically against the Arabs. The state of 
Israel is central in fulfilling some Biblical prophecies such the second coming of Messiah and the final battle of Armageddon and his thousand years reign.

Historically, the evangelical dominant constituencies played a key role in the election for Republican's presidential candidates Jimmy Carter, Ronald Reagan and George W. Bush. The Christin Right appeared in U.S politics in 1970 and they promoted its domestic policies such as banning abortion and opposing gay rights. Between 1977 and 1989 the Christian Right became a political factor and a vessel for evangelical's political development especially in Reagan times. Christian Right "began its alliance with the Republican Party. Reagan and his Republicans successors welcomed and encouraged the close relationship with these religious voters" (Morris, 2014).

This political development in favour of Republican Party under President Reagan was a drastic change in US internal politics in support of Israel as this was early found in the American Jewish community and the Democratic Party. The Neocons had an alliance with Christian Right resulting in a national action block in US and their support for the Republican Party was crucial in raising the political importance of Christian Zionism. One of such organization was "American Israel Public Affairs Committee (AIPAC) shifted to the right in the 1980s and fostered ties with Christian evangelicals and fundamentalists" (Weber, 2004).

By the 1980s Christian Zionism went to heights in America both through Christian Right and the significant activities of Christian's organizations. This development was observed in Ronald Reagan era, but no doubt it had its seeds during the reign of Jimmy Carter who was also a pro- evangelical's president. Two events facilitated political Christian Zionism in U.S in November 1977. Firstly, President Carter proposed a "Palestinian homeland one of the central demands of Arab states and the crucial provision of any agreement to end the Arab-Israeli dispute." (Kaufman, 2006). Secondly, when "in October 1977, the president issued a joint Communiqué with the pro-Arab Soviet Union calling for a new Geneva conference. Seeming to bring Moscow back into the Mideast peace process, the joint statement produced a storm of protest in Israel and in the United States" (Kaufman, 2006).

As a result, this joint statement led to the alienation of several evangelical groups who had helped President Carter in the election campaign of 1976. They showed their anger in a countrywide movement that criticized the policy of President Carter regarding the Holy land politics. This campaign by fundamentalist in US for Israel became a perfect model for later political movements.

Under Reagan, the development of Christian evangelicals in America would have reached to its apex as there were alliance between American Jews and conservative evangelicals. Moral Majority were successful to win the support of millions of priests and other religious personals who lobbied pro-Israel. Moral Majority picked out "Ronald Reagan as their candidate for president in 1980, registered millions of new voters and set about to inform and activate a sleeping giant -80 million Americans committed of faith, family and Judeo-Christian values" (Bonney, 2008).

Many religious groups in U.S used their powers in support of Reagan and the Christian Zionists were a major force among them. The 1980 election and subsequent victory of Ronald Reagan resulted in a pro-Israel administration in U.S history. A lot of Politicians were subscribed to 
Role of religion in American politics: An analysis of the influence of Evangelical Church ...

"futurist premillennial theology and Christian Zionism included Attorney general Ed Meese, secretary of defence Casper Wein-Berger, and Secretary of Interior James Watt" (Masalha, 2007). Majority of Christians Zionists leaders had direct access to President Ronald Reagan. The President also shared a close relationship with some of the notable evangelical leaders in US. In an interview with AIPAC Director Tom Dine, Reagan said "I turn back to your ancient prophets in the Old Testament and signs foretelling Armageddon, and I find myself wondering if we are the generation that's going to see that come about. I do not know if you have noted any of the prophets lately but, believe me, they describe the times we are going through" (Willis \& Willis, 2006)

"The Reagan Administration regularly conducted briefings and seminars for its supporters from the new Christians Right in connections with Israel and the Middle East" (New, 2002). The actions of Christian Zionists between 1977 and 1989 involved supporting Israel was multifaceted: financial in the form of tourism, moral in the shape of statements of support, and political pressure in form of ad campaigns and lobby efforts. The Reagan period was crucial time of growth for Christian Zionism, as well as for alliances between American and Israeli Jews with Christian evangelicals. Similarly, "Reagan well knew the importance of Israel in the apocalyptic scenario as detailed by Hal Lindsay and others. The Dome of the Rock played a key role in this scenario" (New, 2002).

The actions Christian Zionism in the subsequent years would be a prolongation of the currents founded in the 1980s. President Bush intended in 1991 to delay a proposed 10 billion loan to help settle the Jewish immigrants from Russia. There was fear that this amount would be used in making colonies for these new incomers in the West Bank and the Gaza Strip. The domestic pro-Israel lobby was surprised and upset by the intentions of the Bush administration as there were no congressional guarantees. Prime Minister Yitzhak Shamir sought the help of Christian Zionist supporters to pressurize the U.S government. The Israeli supporters organized huge rallies as held by ICEJ in Washington in 1992 to pressure President Bush for approval" (Grzegorzewski, 2010).

Consequently, due to this pressure the president approved the loans in 1992. Christian Zionists are important in Republicans constituencies and has large influence on domestic politics in U.S. In August 1990, the idea of Armageddon was back in the U.S public in the eve of Gulf war. George Bush was the founder of pre-emptive strikes and invasion of Iraq. He justified his actions by blaming Sadam Hussain of having nuclear, biological and chemical weapons. The "patterns of voting behaviour in the U.S include a strong tendency for evangelical Christian to vote for Republican candidates" (Paul, 2018). Majority of the CZ went to the polling stations compared to other groups. They formed alliance with neocons in 1990. The White House wrote a letter to AIPAC.

"We also share a profound desire for a lasting peace in the Middle East. My Administration is dedicated to achieving this goal, one which will guarantee Israel security. At the same time, we will do our utmost to defend and protect Israel, for unless Israel is strong and secure, then peace will always be beyond our grasp. We were with Israel at the beginning, 41 years ago. We are with Israel today. And we will be with Israel in the future. No one should doubt this basic commitment" (White House letter to AIPAC Conference, 1989, May 17). 
Mostly, the politicians base their policies on the endeavours to again re-elect in the next election. President Bush was motivated by his personal beliefs to frame foreign policy of the U.S regarding Israel. This is evident from his rears in the presidential debate among the Republican candidates. The Americans voted for electing the president of the US on November 7, 2000. Meanwhile, all the "Christian fundamentalism was almost unanimous in their vote for George W. Bush, both in 2000 and 2004" (Falk \& Fuller, 2006). G. W. Bush also made a speech to Moral Majority in 1999 however, the contents were not made public during his election campaign.

G. W. Bush junior was also a firm believer of Jesus as their saviour and the Islamophobia of the Christian evangelical's dialogue was evident in his official speeches. US deputy undersecretary of defence for intelligence stated "at one he asked, rhetorically, who the enemy of the United States was. It is not Osama Bin Laden, he stressed. The enemy that comes against our nation is spiritual enemy. His name is Satan. And if you do not believe that Satan is real, you are ignoring the same Bible that tells you about God. For General it followed that God is Christian and Satan Muslim." (Taras, 2012) Under President George Bush junior there was a web of neocons, Christians Zionists organizations and "that web operated with unique autonomy as the president was entirely unequipped to filter their information but was readily persuaded to translate it into action they prescribed. With the Christian Zionists lobby also fully enlisted a sacred and Manichaean aura now radiated from the White House as a U.S policy of regional aggression" (Tilley, 2005).

In 2006 elections, Hamas won majority seats and Bush declared U.S will not deal with Hamas unless and until they change intentions regarding Israel. Christian Zionists allied with Bush were more vocal and were significant in the formation of policy towards the Jewish state. When the bush government condemned the assassination of Palestine leader Abdel Aziz in 2003, Christian Zionists sent thousands of emails to the president. They also threat "that if any more pressure continued to be placed on Israel, they would stay home on Election Day" (Falk \& Fuller, 2006). It is no wonder under such a background the evangelicals showed opposition to some extremist Islamist organizations in the Middle East and side with Israel because of their belief on catastrophic war between Israel and the Muslim world which is the prerequisite for the second coming of Jesus and his divine Kingdom.

Evangelicals Zionists have access to Capital Hill and Congress through the seat of Secretary of state Pompeo and Vice President Mike Pence. Zolinger is a notable Christian Zionists who has profound effects on both Mike Pence and Mike Pompeo. Congressman Mike Pence "who declares himself relatively incurious about eschatology, says that for him Israel was a childhood dream that became a reality. Its territorial integrity is a core belief, founded on his understanding of the Bible. In 2003, with great respect for Israel's right to determine its own policies, Pence told Prime Minister Sharon in his private office in Jerusalem that he was concerned that territorial withdrawal would lead only to a terrorist state" (Spector, 2009). Mike Pence discourse at the summit conference of CUFI marked a juvenile period of evangelical's domination in the Capitol Hill and brought basic transformations towards Protestant evangelical politics in the U.S and prophecies related with Israel.

President Donald Trump began the process of shifting the U.S Embassy to Jerusalem and then approved the Israel occupation of Golan Heights. Further, he gave green lights for Israeli settlements in West Bank. This was complete change in U.S Policy compared to all the previous 
Role of religion in American politics: An analysis of the influence of Evangelical Church ...

policies. This hinders the concept of two state solutions for Palestinians. These policies are in direction of Christian Zionists who see no place for Arabs in greater Israel. "Clearly, as the religious right grew in power in the U.S, so too did a radical shift in American foreign policy toward Israel becomes inevitable" (McGlasson, 2019). Similarly, Donald Trump Choses the "Nakba Day" or "Independence Day for Israel" to shift the U.S Embassy's to Jerusalem which shows his commitment to Israel.

Robert Jeffers, another strong "Christian Zionist and profound Trump supporter, was present at the dedication of what will become the new embassy in Jerusalem and offered an official prayer. As he prayed, the spoke of the Messiah, the fulfilment of prophecies, the great leadership of President Donald Trump given by God, a leader who stands on the right side of God" (McGlasson, 2019).

The Christian Zionists consider President Trump not only a supporter of apocalypse and end time prophecies but also a notable figure within it. As pointed out by McGlasson "at any rate there is little doubt that Christian Zionism-which is supported by a vast majority of evangelicals in America-is decidedly in favour of Trumpism" (McGlasson, 2019). "Trump's indebtedness to the evangelicals is one reason to be worried about his policies in the region. The Christian Zionists have no interest in fairness, justice or international law. Rather, they are prepared to inflame tensions in the Middle East - and even trigger Armageddon itself - if they think it might benefit Israel and further God's prophecy" (Cook, 2018).

\section{Conclusion}

The scriptures of Bible shape the devotee's thoughts and ideas of truth about the Arab-Israel conflict, and they choose their party according to it. Academics have given little attention to the power and supremacy of religious organizations and faith system for instance the Christian Zionists and how they have strived to employ influence on U.S diplomatic policy towards Israel-Palestine conflict. Presidential candidates have various schemes to increase military and financial aid to Israel in to clinch the endorsement of Jewish voters. Since Harry Truman acknowledgement of Israel, mostly the Democrats support Israel compared to Republicans. In 1980 Ronald Reagan introduced a large number of neoconservatives and Zionists into the Republican Party and made it pro-Israel party. During the Carter's era these conservatives had affiliation with Republican Party. These conservative supported Israel because they conceived hate for Israel is hate to democracy. The Moral majority was one their most influential group under the leadership of Jerry Falwel. The Christian Coalition under Pat Robertson was another influential group in the Republican Party.

This fact is also obvious that decision makers select the favours the wishes of evangelicals. The presidential candidates usually act along the lines that start from statements which portray an unequivocal support for Israel. The U.S is downplaying the Palestinians for sixty-five years of the conflict. This is best explained by Merkly (2004) "as the war against global terrorism has unfolded, Christen Zionists have provided some ideological reinforcement to arguments that make complete sense to patriotic conservatives in terms of the national security for the United State." Christian Zionists chalked up its golden age of credit, weight and prestige when the Christian Right was a strong political unit in the U.S. This was primarily in the period of 1980s with its coalition with the Moral Majority and after 1994 with upsurge of the Christian Coalition of America and now in the Donald Trump era. Christian Zionism is not only an 
ideology now but a strong political force in the contemporary internal relations. Its members are increasing day by day and it form alliances with other Zionists organizations. They are essential part of the Donald Trump administration and thus a danger for appeasement in occupied Palestine. They not only provide political support to Israel, but they also provide financial support for new settlements in holy land.

\section{References}

Abrams, E. (2002). The influence of faith: Religious groups and US foreign policy. Rowman $\&$ Littlefield.

Ariel, Y. S. (2000). Evangelizing the chosen people: Missions to the Jews in America, 18802000. University of North Carolina.

Bonney, R. (2008). False Prophets: The clash of civilizations and the global war on terror (Vol. 9). Peter Lang.

Bufardi, C. (2014). Online Facebook discussion-correspondence.

Clark, V. (2007). Allies for Armageddon: The rise of Christian Zionism. Yale University.

Cook, J. (2018). Under Trump, the Israel lobby is a Hydra with many heads. Middle East Eye. https://www.middleeasteye.net/columns/under-trump-israel-lobby-has-grownmany-headed-hydra-1970608671

Cohn-Sherbok, D. (2012). Introduction to Zionism and Israel. Continuum International.

Demy, T. J., \& Shaw, J. M. (Eds.). (2019). Religion and contemporary politics: A Global Encyclopaedia [2 Volumes]. ABC-CLIO.

Falk, G., \& Fuller, M. E. (2006). The restoration of Israel: Christian Zionism in religion, literature, and politics (Vol. 257). Peter Lang.

Goldman, S. (2018). God's Country: Christian Zionism in America. University of Pennsylvania.

Grzegorzewski, M. G. (2010). The Christian Zionist Lobby and U.S.-Israel policy. https://digitalcommons.usf.edu/etd/3671/

Kaufman, B. I. (2006). Presidential profiles, the carter years. Facts on File.

Krauthammer, C. (2004). Democratic realism: An American foreign policy for a unipolar world. American Enterprise Institute.

Marsden, D. L. (2008). For God's sake: the Christian right and US foreign policy. Bloomsbury.

Masalha, N. (2007). The Bible and Zionism: Invented traditions, archaeology and postcolonialism in Palestine-Israel (Vol. 1). Zed Books.

Mearsheimer, J. J., \& Walt, S. M. (2006). The Israel lobby and US foreign policy. KSG Faculty Research Working Paper Series RWP06-011, March 2006.

Merkley, P. C. (2004). American presidents, religion \& Israel: Heirs of Cyrus. Greenwood.

Morris, P. F. (Ed.). (2014). The Gospel and Israel: The Edersheim Lectures. Wipf and Stock.

McGlasson, P. C. (2019). Choose you this day: The Gospel of Jesus Christ and the politics of Trumpism. Wipf and Stock.

New, D. S. (2002). Holy war: the rise of militant Christian. Jewish, and Islamic fundamentalism, McFarland \& Co., Jefferson, $N C$.

Prophet, P. (2009). His dream interpreters. Zolons.

Shannon, V. P. (2020). Balancing act: US foreign policy \& the Arab-Israel conflict. Routledge.

Sharif, R. S. (1983). Non-Jewish Zionism: Its roots in Western history. Zed Press.

Spector, S. (2009). Evangelicals and Israel: The story of American Christian Zionism. Oxford University. 
Role of religion in American politics: An analysis of the influence of Evangelical Church ...

Sizer, Stephen. (2004). Christian Zionism: Road-map to Armageddon? IVP Academics. Sizer, Stephen. (2005). Christian Zionism its history theology and Politics. Aaargh.

Stanislawski, M. (2017). Zionism: A Very Short Introduction, Oxford University.

Taras, R. (2012). Xenophobia and Islamophobia in Europe. Edinburgh University.

Terry, Janice. J. (2005). U.S foreign policy in the Middle East: The role of Lobbies and Special Interest Groups, Pluto.

Tilley, V. (2005). The one-state solution: a breakthrough for peace in the Israeli-Palestinian deadlock. Manchester University.

Thomas, M. (2007). American policy toward Israel: The power and limits of beliefs. Routledge.

Weber, T. P. (2004). On the road to Armageddon: How evangelicals became Israel's best friend (p. 336). Baker Academic.

Willis, J., \& Willis, B. (2005). Armageddon now: The end of the world A to Z. Visible Ink. 